\title{
Antibacterial and anti-staphylococcal enterotoxin activities of phenolic compounds
}

\author{
Mariana Albano, Fernanda Cristina Bérgamo Alves, Bruna Fernanda Murbach Teles Andrade, \\ Lidiane Nunes Barbosa, Ana Flávia Marques Pereira, Maria de Lourdes Ribeiro de Souza da Cunha, \\ Vera Lucia Mores Rall, Ary Fernandes Júnior*
}

Department of Microbiology and Immunology, Institute of Biosciences of Botucatu, Universidade Estadual Paulista “Júlio de Mesquita Filho", 18618-689 Botucatu, SP, Brazil

\section{A R T I C L E I N F O}

\section{Article history:}

Received 14 April 2016

Received in revised form 31 August 2016

Accepted 2 September 2016

Available online 4 September 2016

\section{Keywords:}

Phenolic compounds

Essential oil

Staphylococcus aureus

Synergism

Staphylococcal enterotoxins

\begin{abstract}
A B S T R A C T
Food safety has been an established research field for many decades. This report describes the antibacterial and anti-staphylococcal enterotoxin properties of major phenolic compounds found in essential oils (cinnamaldehyde, citronellol, eugenol, geraniol and terpineol). The determination of minimum inhibitory concentrations (MIC) against Gram-negative and Gram-positive strains, including methicillin-resistant Staphylococcus aureus (MRSA) and enterotoxin-producing S. aureus (enterotoxins A, B, C and D) were evaluated. Cinnamaldehyde displayed MIC values ranging from 100 to $400 \mu \mathrm{g} / \mathrm{mL}$ against Gram- positive and Gram-negative bacteria, while the other four compounds showed similar values only against Gram-negative bacteria. For Grampositive strains, MIC values ranged from approximately $800-1750 \mu \mathrm{g} / \mathrm{mL}$. Interactions between the compounds and antibacterial drugs were evaluated by disc diffusion and time-kill curve assays against MRSA. Combinations of phenolic compounds that included gentamicin showed the greatest synergistic effect. In vitro treatments with subinhibitory concentrations of phenolic compounds resulted in a decreased production of enterotoxins $B$ and $C$ (SEB and SEC). Transmission electron microscopy was performed to evaluate mechanisms of action for cinnamaldehyde and geraniol against $E$. coli and MRSA. Cells treated with compounds showed complete loss of membrane integrity, separation of the cytoplasmic membrane from the cell wall, cytoplasmic content leakage and cytoplasmic polarization. Thereby, this work showed in vitro potential of using combinations of phenolic compounds and antimicrobial drugs against $S$. aureus and the virulence of $S$. aureus enterotoxin producers. Industrial relevance: Antimicrobial compounds derived from plants are a focus of renewed interest as potential substitutes for artificial food preservatives. In our study subinhibitory concentrations of phenolic compounds had a significant effect on the quantity of enterotoxins produced by Staphylococcus aureus and inhibited the growth of Escherichia coli, Salmonella Enteritidis and other bacteria in microbiological media.
\end{abstract}

(c) 2016 Elsevier Ltd. All rights reserved.

\section{Introduction}

Foodborne diseases are a major concern worldwide. Approximately 250 different types of foodborne diseases are described and bacteria are responsible for $2 / 3$ of the outbreaks (Le Loir, Baron, \& Gautier, 2003). Staphylococcal food poisoning is one of the most common foodborne illnesses and results from ingestion of preformed enterotoxin in food, produced and released by strains of coagulase-positive staphylococci, particularly S. aureus (Hennekinne et al., 2009). Thereby, the impact of S. aureus resistance on clinical outcomes stimulates the search for new antimicrobial drugs aiming the treatment of foodborne diseases caused by these bacteria.

\footnotetext{
* Corresponding author.

E-mail address: ary@ibb.unesp.br (A. Fernandes Júnior).
}

Volatiles compounds from plant sources could provide alternative therapies since many possess excellent therapeutic properties and do not cause bacterial resistance (Mitić-Ćulafić, Vuković-Gačić, KneževićVukčević, Stanković, \& Simić, 2005). Thus, a new alternative strategy against S. aureus is to target bacterial virulence factors (e.g. hemolysins, enterotoxins, adhesins) (Song et al., 2009) to minimize the effects of the presence of such bacteria in food.

Antibacterial drugs or antibiotics have been used to treat infectious diseases, however, bacteria have responded by increasing the level and complexity of their mechanisms of resistance (Tenover, 2006). Multidrug resistance is a result of antibiotic misuse and selection pressure (Tohidpour, Sattari, Omidbaigi, Yadegar, \& Nazemi, 2010). Therefore, the use of broad-spectrum antibiotics, rather than narrow-spectrum drugs, increases antibiotic resistance (Barbosa \& Levy, 2000). A wide range of bacteria can be listed as resistant to several antibacterial drugs in hospital environments and community. Staphylococci are of 
great epidemiological concern for contemporary invasive medicine and $S$. aureus has the strongest virulence potential among all staphylococcal species. Since 1960 methicillin-resistant $S$. aureus (MRSA) has become one key pathogen responsible for healthcare-associated infections, which are usually difficult to treat (Bigos \& Denys, 2008).

In this context, essential oils (EOs) have been screened for their potential use as alternatives to drugs, for treatment in numerous infectious processes, as well as natural food preservatives (Schuenzel \& Harrison, 2002; Tepe, Daferera, Sökmen, Polissiou, \& Sökmen, 2004). EOs can comprise more than 70 compounds, principally polyphenols, terpenes, monoterpenes and sesquiterpenes, and some of these compounds may represent more than $85 \%$ of the total content in the EOs (Cowan, 1999; Nascimento et al., 2007). EOs are considered the most important antimicrobial agents present in plants and have been studied for their antibacterial (Mourey \& Canillac, 2002; Oussalah, Caillet, Saucier \& Lacroix, 2007; Silva, Barbosa, Seito \& Fernandes Júnior, 2012; Barbosa et al., 2015; Moritz, Barbosa, Saeki \& Fernandes Júnior, 2015), antiparasitic (George, Smith, Shiel, Sparagano, \& Guy, 2009), antifungal (Fitzgerald, Stratford, \& Narbad, 2003), antiviral (Astani, Reichling, \& Schnitzler, 2011), insecticidal (Enan, 2001; Kim, Roh, Kim, Lee, \& Ahn, 2003), antioxidant (Brenes \& Roura, 2010) and anti-inflammatory properties (Andrade, Conti, Santiago, Fernandes Júnior, \& Sforcin, 2014; Burt, 2004; Delamare, Moschen-Pistorello, Artico, Atti-Serafini, \& Echeverrigaray, 2007; Kordali et al., 2005).

Considering the importance of $S$. aureus in food and medical microbiology, several studies have been conducted to enhance the action of antimicrobials drugs. Indeed, synergism between natural antimicrobials and conventional antimicrobial drugs has been reported for S. aureus (Fernandes Júnior, Balestrin, Betoni, Orsi, Cunha and Montelli, 2005; Mantovani, Rall, Batalha, Fernandes, \& Fernandes Júnior, 2008; Zago, Ushimaru, Barbosa, \& Fernandes Junior, 2009; Silva et al., 2013; Qian et al., 2015). Therefore, in this study, the antibacterial and anti-enterotoxin properties of five phenolic compounds found in EOs were evaluated against $S$. aureus strains, with emphasis on MRSA.

\section{Materials and methods}

\subsection{Bacterial strains and growth culture conditions}

The staphylococcal strains that were used included: MRSA (ATCC 33591), methicillin-sensitive S. aureus (MSSA) (ATCC 25923) and enterotoxigenic S. aureus strains (ATCC 13565, ATCC 14558, ATCC 19095 and ATCC 23235). The Gram-negative strains used were: Salmonella Enteritidis (ATCC 13076), Pseudomonas aeruginosa (ATCC 27853) and Escherichia coli serotype 0157:H7 (ATCC 43895). MRSA and MSSA strains also were isolated from human specimens at the University Hospital of Botucatu Medical School, São Paulo, Brazil (Universidade Estadual Paulista "Júlio de Mesquita Filho") and enterotoxigenic S. aureus strains were isolated from food samples. Stock cultures were frozen at $-80^{\circ} \mathrm{C}$ in culture medium plus glycerol. For experimental use, strains were maintained in brain heart infusion (BHI) (Difco, Becton Dickinson and Company, Franklin Lakes, $\mathrm{NJ}$ ) agar slopes at $4^{\circ} \mathrm{C}$. The use of bacterial strains from human specimens was approved by our Institutional Committee on Human Research (document 4375-2012), according to the ethical principles for medical research involving human subjects.

\subsection{Antimicrobial compounds}

Five phenolic compounds, normally found in EOs, were tested: geraniol (Ger) (Cymbopogon martinii), cinnamaldehyde (Cin) (Cinnamomum sp.), $\beta$-citronellol (Cit) (Cymbopogon sp.), eugenol (Eug) (Syzygium aromaticum) and terpineol (Ter) (Melaleuca alternifolia). All compounds used were obtained from Sigma-Aldrich (St. Louis, MO). The working solutions were prepared in a 1:1 ratio of dimethyl sulfoxide (Sigma-Aldrich) and sterile water to standardize the compounds to $1000 \mu \mathrm{g} / \mathrm{mL}$.

\subsection{Determination of minimum inhibitory concentrations}

Minimum inhibitory concentrations (MIC) of the compounds were measured by resazurin microtiter assay (REMA) (Martin, Camacho, Portaels, \& Palomino, 2003) with modifications for MRSA, MSSA, S. aureus enterotoxin A producer (SEA), S. Enteritidis, P. aeruginosa and E. coli. Seven clinical isolates and one standard strain (ATCC) of each species were used. Various concentrations of the compounds (from 100 to $1800 \mu \mathrm{g} / \mathrm{mL}$ ) were placed in 96-well sterile microtiter plates containing Mueller-Hinton Broth (MHB) (Difco, Becton Dickinson and Company, Franklin Lakes, NJ). Inocula were prepared by diluting overnight cultures $\left(37^{\circ} \mathrm{C} / 18-24 \mathrm{~h}\right)$ in saline solution until a turbidity equivalent to 0.5 McFarland standard (approximately $10^{8}$ colony-forming units $(\mathrm{CFU}) / \mathrm{mL}$ ) was obtained. Aliquots of $100 \mu \mathrm{L}$ were then added to each well, resulting in a final volume of $200 \mu \mathrm{L}$ and approximately $10^{5} \mathrm{CFU} /$ $\mathrm{mL}$ per well. The negative control consisted of $100 \mu \mathrm{L}$ of $\mathrm{MHB}$ and $100 \mu \mathrm{L}$ of cell suspension. Plates were incubated at $37^{\circ} \mathrm{C} / 18-24 \mathrm{~h}$, prior to enumeration. MIC was defined as the lowest concentration of the compound that inhibited the visible microorganism growth after incubation. Fifty $\mu \mathrm{L}$ of resazurin $(0.01 \%)$ was added to each well and a color change from blue to pink was indicative of viable bacterial cells. The corresponding values of $\mathrm{MIC}_{90 \%}$ for each group of microorganisms were calculated. All experiments were performed in duplicate.

\subsection{Synergism assays according to the Kirby-Bauer protocol}

Assays were performed using the Kirby-Bauer disc diffusion method adapted by Stepanovic, Antic, Dakic \& Svabic-Vlahovic (2003) in cationadjusted Mueller-Hinton II agar (MHA) (Difco, Becton, Dickinson and Company, Franklin Lakes, NJ), with the addition of $0.5 \%$ Tween 80 . Amounts corresponding to 25\% MIC of each compound were mixed individually with the medium and poured into Petri dishes. Bacterial density was adjusted to $0.5 \mathrm{McF}$ arland standard. Using sterile cotton swabs, MRSA and MSSA were inoculated on the medium. Discs of oxacillin (Oxa, $1 \mu \mathrm{g}$ ), gentamicin (Gen, $10 \mu \mathrm{g}$ ), erythromycin (Ery, $15 \mu \mathrm{g}$ ), sulfazotrin (Sul, $25 \mu \mathrm{g}$ ), vancomycin (Van, $30 \mu \mathrm{g}$ ), penicillin G (Pen, $10 \mathrm{U}$ ) levofloxacin (Lev, $5 \mu \mathrm{g}$ ), tetracycline (Tet, $30 \mu \mathrm{g}$ ) and linezolid (Lin, $30 \mu \mathrm{g}$ ) were placed on the surface of inoculated MHA. Culture medium prepared without the compounds was used as the control. The plates were incubated at $37^{\circ} \mathrm{C} / 24 \mathrm{~h}$. After incubation, the zone of inhibition formed was measured in millimeters $(\mathrm{mm})$, and synergy was considered positive when the halo of the culture media containing compounds showed an increase in size compared to the control.

\subsection{Time-kill assay}

An assay was performed to identify synergistic interactions among the compounds and antimicrobial drugs, according to the National Committee for Clinical Laboratory Standard guidelines (Clinical and Laboratory Standards Institute, CLSI, 2012). MRSA strain (ATCC 33591) $\left(10^{5} \mathrm{CFU} / \mathrm{mL}\right.$ ) was incubated with either the compounds alone at $25 \%$ MIC or in combination with antimicrobial drugs in MHB (Difco, Becton Dickinson and Company, Franklin Lakes, NJ) (Mahon \& Manuselis, 1995). Culture media prepared without compounds and/or antimicrobial drugs were treated similarly as the controls. Aliquots were taken from each tube and diluted serially using sterile saline at intervals of $0,2,4,6$, 8 and $24 \mathrm{~h}$, and inoculated onto agar plates, which were then incubated at $37^{\circ} \mathrm{C} / 24 \mathrm{~h}$. Subsequently colonies were enumerated and expressed as $\mathrm{CFU} / \mathrm{mL}$ (Hamoud, Sporer, Reichling, \& Wink, 2012). After 18-24h incubation, an antimicrobial agent was considered: bactericidal, when it caused a reduction $\geq 3 \log _{10} \mathrm{CFU} / \mathrm{mL}$; and bacteriostatic when it caused a reduction in the bacterial count of $<3 \log _{10} \mathrm{CFU} / \mathrm{mL}$. A combination was considered synergistic when it caused a reduction 
Table 1.

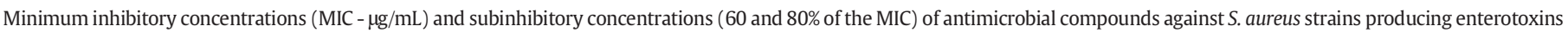
A (ATCC 13565 - SEA), B (ATCC 14558 - SEB), C (ATCC 19095 - SEC) and D (ATCC 23235 - SED).

\begin{tabular}{|c|c|c|c|c|c|c|c|c|c|c|c|c|c|c|c|}
\hline \multicolumn{16}{|c|}{$\mathrm{MIC}(\mu \mathrm{g} / \mathrm{mL})$} \\
\hline \multirow[t]{2}{*}{ Strain } & \multicolumn{3}{|c|}{ Eugenol } & \multicolumn{3}{|c|}{ Terpineol } & \multicolumn{3}{|c|}{ Cinnamaldehyde } & \multicolumn{3}{|c|}{ Citronellol } & \multicolumn{3}{|c|}{ Geraniol } \\
\hline & MIC & $60 \%$ & $80 \%$ & MIC & $60 \%$ & $80 \%$ & MIC & $60 \%$ & $80 \%$ & MIC & $60 \%$ & $80 \%$ & MIC & $60 \%$ & $80 \%$ \\
\hline 13565 & 1200 & 720 & 960 & 1100 & 660 & 880 & 200 & 120 & 160 & 900 & 540 & 720 & 800 & 480 & 640 \\
\hline 14558 & 900 & 540 & 720 & 700 & 420 & 560 & 500 & 300 & 400 & 1100 & 660 & 880 & 500 & 300 & 400 \\
\hline 19095 & 900 & 540 & 720 & 1300 & 780 & 1040 & 300 & 180 & 240 & 1000 & 600 & 800 & 900 & 540 & 720 \\
\hline 23235 & 1100 & 660 & 880 & 900 & 540 & 720 & 500 & 300 & 400 & 1200 & 720 & 960 & 1000 & 600 & 800 \\
\hline
\end{tabular}

$\geq 2 \log _{10} \mathrm{CFU} / \mathrm{mL}$ after $18-24 \mathrm{~h}$ incubation (Rochon-Edouard, PestelCaron, Lemeland, \& Caron, 2000).

\subsection{Influence of phenolic compounds on staphylococcal enterotoxin production}

The effects of the phenolic compounds on enterotoxin production were evaluated. S. aureus strains producing enterotoxins A (SEA), B (SEB), C (SEC) and D (SED) (ATCC 13565, ATCC 14558, ATCC 19095 and ATCC 23235, respectively) were incubated in tryptic soy broth (TSB) (Difco, Becton Dickinson and Company, Franklin Lakes, NJ) $\left(37^{\circ} \mathrm{C} / 24 \mathrm{~h}\right.$ ) in the presence of $60 \%$ and $80 \%$ MIC of each compound (Table 1), obtained using the REMA method (Section 2.3). Controls containing TSB and either compound or bacteria only were treated similarly. After incubation, each sample was centrifuged $\left(9000 \mathrm{~g}, 4^{\circ} \mathrm{C}, 30 \mathrm{~min}\right)$, and the supernatants were examined for enterotoxin production, using a reversed passive latex agglutination kit (SET-RPLA) (Oxoid, Japan). Assays were conducted, according to manufacturer's instructions. Serial dilutions of the supernatants were performed to determine the concentration of enterotoxin produced. Latex controls showed no interference in enterotoxin detection by all compounds tested.

\subsection{Effect of cinnamaldehyde and geraniol on bacterial morphology}

To elucidate the mechanism of action of Cin and Ger against bacterial cells, transmission electron microscopy (TEM) was carried out, using a modified method of Moosavy et al. (2008). Overnight cultures of MRSA (ATCC 33591) and E. coli (ATCC 43895) strains (BHI at $37^{\circ} \mathrm{C} / 24 \mathrm{~h}$ ) were treated with MIC and $2 \times$ MIC of each compound. Contact between the bacteria and phenolic compounds was maintained for $2 \mathrm{~h}$. Subsequently, $3 \mathrm{~mL}$ of Karnowski solution was added and the samples then centrifuged $\left(1500 \mathrm{~g} / 4^{\circ} \mathrm{C} / 20 \mathrm{~min}\right)$. The supernatants were discarded and Karnowski solution was added to cover the pellet. The samples were then incubated for $2 \mathrm{~h}$ at room temperature and maintained at $4^{\circ} \mathrm{C}$ for $24 \mathrm{~h}$. Postfixation was performed using osmium tetroxide solution $(1 \%)$ in $0.1 \mathrm{M}$ phosphate buffer $(\mathrm{pH} 7.3)$ for $2 \mathrm{~h}$, followed by material dehydration in acetone and impregnation into araldite blocks to obtain ultrafine sections. The sections were subsequently stained with uranyl acetate and lead citrate. Finally, samples were analyzed and photographed (digital imaging) with a transmission electron microscope (CM 100, Philips) operated at $80 \mathrm{kV}$.

\subsection{Statistical analysis}

Data obtained from the REMA and time-kill assays were analyzed by Kruskal-Wallis one-way analysis of variance (ANOVA) and StudentNewman-Keuls method (multiple comparisons) with a significance level of 5\%. Disc diffusion results were compared using Mann-Whitney test $(p<0.05$ ), and enterotoxin production using non-parametric Kruskal-Wallis test with scores relating to subinhibitory concentrations of the compounds used to compare between treatments and controls.

\section{Results and discussion}

\subsection{Determination of minimum inhibitory concentrations}

The $\mathrm{MIC}_{90 \%}$ values of the five phenolic compounds evaluated are shown in Table 2 . Cin revealed the greatest antibacterial activity among all the bacteria tested, with $\mathrm{MIC}_{90 \%}$ ranging from 100 to $400 \mu \mathrm{g} / \mathrm{mL}$. Moreover, previous studies have reported its antimicrobial (Kaskatepe et al., 2016; Ooi et al., 2006; Zhu, Du, Fox, \& Zhu, 2016), antioxidant and anticancer properties (Li, Kong, \& Wu, 2013; Thomas \& Kuruvilla, 2012; Wang, Wang, \& Yang, 2009). In particular, Budri et al. (2015) reported the effect of cinnamon (Cinnamomum zeylanicum) EO and its major phenolic compound (Cin) against S. aureus biofilms on various surfaces, with significant inhibition on polystyrene and stainless steel surfaces. In the current study, Gram-negative bacteria were more susceptible to the phenolic compounds investigated than Gram-positive bacteria. The $\mathrm{MIC}_{90 \%}$ ranged from 200 to $1750 \mu \mathrm{g} / \mathrm{mL}$ against Grampositive bacteria. Among the bacterial strains investigated, MRSA was most resistant to the compounds, while $P$. aeruginosa strains were most susceptible. Other compounds showed also similar values against the others Gram-negative bacteria.

Eug has an excellent bactericidal activity against a wide range of organisms, including E. coli, P. aeruginosa (Walsh et al., 2003) and Listeria monocytogenes (Filgueiras \& Vanetti, 2006). The principal antibacterial mechanism of Eug is its disruption of the bacterial cytoplasmic membrane, which increases its non-specific permeability (Li et al., 2015). Moreover, the hydrophobic nature of Eug enables it to penetrate into the outer lipopolysaccharide membrane of Gram-negative bacteria, altering the cell wall structure, and subsequently resulting in the leakage of intracellular constituents (Burt, 2004).

\subsection{Synergism}

Synergism between the phenolic compounds and antibacterial drugs could assist in the elimination of MRSA and other pathogenic bacteria. The compound and antimicrobial drug combinations used against MRSA showed a synergistic effect between Eug/Gen, Eug/Van, Eug/Lin, Cit/Gen, Cit/Van, Cit/Lev Cit/Lin and Ter/Lin, whereas there were no synergistic interactions with Ger (Table 2).

Table 2.

Minimum inhibitory concentrations (MIC $\mathrm{M0 \%}_{\mathbf{9 0}}$ ) of antimicrobial compounds against bacterial strains.

\begin{tabular}{lccccc}
\hline & \multicolumn{5}{c}{ MIC $_{90 \%}(\mu \mathrm{g} / \mathrm{mL})$} \\
\cline { 2 - 6 } Bacteria & Eugenol & Terpineol & Cinnamaldehyde & Citronellol & Geraniol \\
\hline MSSA & $1300^{\mathrm{a}}$ & $1550^{\mathrm{b}}$ & $300^{\mathrm{c}}$ & $1500^{\mathrm{d}}$ & $800^{\mathrm{e}}$ \\
MRSA & $1600^{\mathrm{a}}$ & $1700^{\mathrm{b}}$ & $400^{\mathrm{c}}$ & $1750^{\mathrm{b}}$ & $1450^{\mathrm{a}}$ \\
Enterotoxigenic & $1350^{\mathrm{a}}$ & $1000^{\mathrm{b}}$ & $200^{\mathrm{c}}$ & $900^{\mathrm{d}}$ & $900^{\mathrm{d}}$ \\
S. aureus & & & & & \\
S. Enteritidis & $250^{\mathrm{a}}$ & $250^{\mathrm{a}}$ & $100^{\mathrm{b}}$ & $200^{\mathrm{c}}$ & $150^{\mathrm{c}}$ \\
P. aeruginosa & $200^{\mathrm{a}}$ & $200^{\mathrm{b}}$ & $150^{\mathrm{a}}$ & $200^{\mathrm{b}}$ & $200^{\mathrm{b}}$ \\
E. coli & $250^{\mathrm{a}}$ & $250^{\mathrm{a}}$ & $100^{\mathrm{b}}$ & $250^{\mathrm{a}}$ & $200^{\mathrm{c}}$ \\
\hline
\end{tabular}

Different letters in the same row indicate a significant difference at $p \leq 0.05$. 
Table 3.

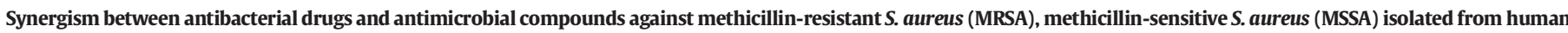
specimens by Kirby\&Bauer protocol (Stepanovic et al., 2003).

\begin{tabular}{|c|c|c|c|c|c|c|c|c|c|c|}
\hline & \multicolumn{2}{|c|}{ Eugenol } & \multicolumn{2}{|c|}{ Terpineol } & \multicolumn{2}{|c|}{ Citronellol } & \multicolumn{2}{|c|}{ Cinnamaldehyde } & \multicolumn{2}{|c|}{ Geraniol } \\
\hline & MRSA & MSSA & MRSA & MSSA & MRSA & MSSA & MRSA & MSSA & MRSA & MSSA \\
\hline Oxa & - & - & - & - & - & - & - & - & - & - \\
\hline Gen & + & + & + & + & + & + & - & + & - & - \\
\hline Ery & - & - & - & - & - & - & - & + & - & - \\
\hline Sul & - & - & - & - & - & + & - & + & - & - \\
\hline Van & + & - & - & - & + & + & - & + & - & - \\
\hline Pen G & - & - & - & - & - & - & - & - & - & - \\
\hline Lev & - & - & + & - & + & + & - & + & - & - \\
\hline Tet & - & - & - & - & - & + & - & + & - & - \\
\hline Lin & + & - & + & - & + & + & - & + & - & - \\
\hline
\end{tabular}

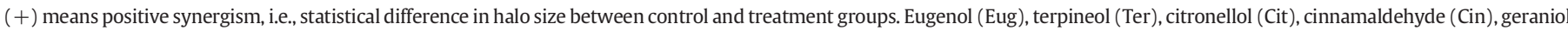
(Ger), oxacillin (Oxa), gentamicin (Gen); erythromycin (Ery), sulfazotrin (Sul), vancomycin (Van); penicillin G (Pen G), levofloxacin (Lev), tetracycline (Tet), linezolid (Lin).

Compared to the disc diffusion assay data, which showed numerous synergistic interactions between the antimicrobial phenolics and antibacterial drugs (10 synergistic interactions against MRSA strains -
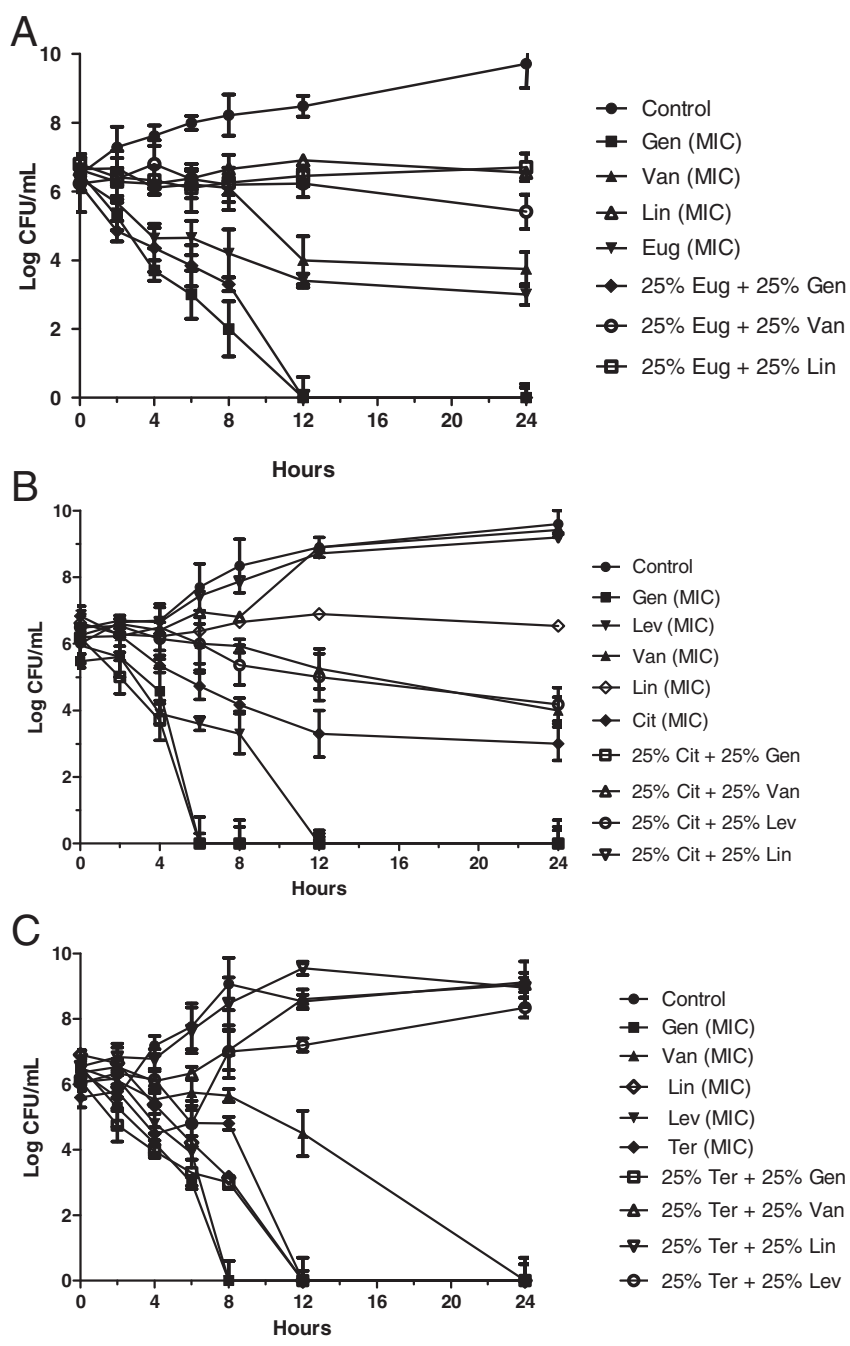

Fig. 1. Time-kill curve of compounds and antibacterial drugs against MRSA (ATCC 33591). (A) Time-kill curves of MIC of eugenol (Eug), gentamicin (Gen), vancomycin (Van) and linezolid (Lin), alone, and in combination with $25 \%$ of MIC of each substance; (B) Timekill curves of MIC of citronellol (Cit), gentamicin (Gen), vancomycin (Van), levofloxacin (Lev) and linezolid (Lin), alone, and in combination with $25 \%$ of MIC of each substance; (C) Time-kill curves of MIC of terpineol (Ter), gentamicin (Gen), vancomycin (Van), levofloxacin (Lev) and linezolid (Lin), alone, and in combination with $25 \%$ of MIC of each compound.
Table 3) only four combinations were confirmed by time-kill curve (Fig. 1). The time-kill curve assay is a more refined and accurate method to study interactions between antimicrobial substances. The antimicrobial compounds that showed the most promising results in the time-kill assay (Eug, Cit and Ter) were chosen for further investigation. As observed in Fig. 1, all three combinations with Gen showed a synergistic and bactericidal effect. For the first $2 \mathrm{~h}$ of MRSA contact with Eug and drugs, the Eug/Gen combination showed a greater decrease in colony count compared to the MIC of Eug and Gen, alone. Similar results were observed for Gen/Cit and Gen/Ter, although the number of colonies remained higher than that of Eug/Gen, for up to $6 \mathrm{~h}$ of contact. Eug/Van, Eug/Lin and Cit/Lev showed bacteriostatic effects, whereas only Cit/Lev was synergistic.

Alves et al. (2016) demonstrated a synergistic bactericidal effect of nisin when combined with phenolic compounds (carvacrol, thymol, Cin and Eug) against S. aureus and L. monocytogenes. Palaniappan and Holley (2010) found that thymol, carvacrol and Cin acted synergistically with Pen, ampicillin and bacitracin against $S$. aureus resistant to these antibiotics. The exact mechanism for the decreased antibiotic resistance by natural compounds is unknown but has been attributed to a structural change in the bacteria. Indeed, the natural compounds may facilitate penetration of the drug through the outer layers of the bacterial cell wall, act to block the inhibitory effects of protective enzymes, or interfere with single or multiple metabolic targets of the antibiotic (Hemaiswarya, Kruthiventi, \& Doble, 2008). Zhao, Hu, Hara, and Shimamura (2002) found that the green tea polyphenol, epigallocatechin gallate (EGCg), inhibited the activity of penicillinase produced by S. aureus, restoring the activity of Pen. Similar results were reported by Hu et al. (2002), showing that EGCg synergistically enhanced the activity of carbapenems against MRSA. Shiota et al. (2000) reported that tellimagrandin I, a polyphenol extracted from red rose (Rosa canina L.) petal, substantially decreased the MIC of $\beta$-lactam antibiotics against MRSA. Similarly, corilagin, an active compound extracted from Aretostaphylos uva-ursi, decreased the MIC of $\beta$-lactam antibiotics (oxacillin and cefmetazole) against MRSA (Shimizu et al., 2001).

\subsection{Influence of phenolic compounds on staphylococcal enterotoxin production}

Subinhibitory concentrations of the phenolic compounds had a significant effect on the total quantity of enterotoxin produced (Tables 4 to 7). For example, Eug, Cit and Ger $(p<0.001)$ had a significant influence on SEA production (Table 4). Ter and Eug completely inhibited SEB production at both concentrations tested (Table 5). SEC production was the most sensitive to the phenolics (Table 6), while the opposite effect was observed for SED production, which was not influenced by any of the compounds (Table 7).

Extracellular protein production can be modulated by subinhibitory concentrations of EOs (e.g. oils of bay, cinnamon and clove) and, 
Table 4.

Production of staphylococcal enterotoxin type A (SEA) by S. aureus ATCC 13565 cultured with subinhibitory concentrations of phenolic compounds.

\begin{tabular}{|c|c|c|c|c|c|c|c|c|c|c|c|}
\hline \multirow[b]{2}{*}{ Dilution } & \multirow[b]{2}{*}{ Control } & \multicolumn{2}{|c|}{ Eugenol } & \multicolumn{2}{|c|}{ Terpineol } & \multicolumn{2}{|c|}{ Cinnamaldehyde } & \multicolumn{2}{|c|}{ Citronellol } & \multirow{2}{*}{$\frac{\text { Geraniol }}{60 \%}$} & \multirow[b]{2}{*}{$80 \%$} \\
\hline & & $60 \%$ & $80 \%$ & $60 \%$ & $80 \%$ & $60 \%$ & $80 \%$ & $60 \%$ & $80 \%$ & & \\
\hline $1: 1$ & +++ & $++^{*}$ & $++^{*}$ & +++ & +++ & +++ & +++ & $++^{*}$ & $++^{*}$ & $++^{*}$ & $++^{*}$ \\
\hline $1: 10$ & +++ & $++^{*}$ & $++{ }^{*}$ & +++ & +++ & +++ & +++ & $++*$ & $++*$ & $++^{*}$ & $++^{*}$ \\
\hline $1: 100$ & +++ & $++*$ & $++{ }^{*}$ & +++ & ++ & +++ & +++ & $++{ }^{*}$ & $++^{*}$ & $++^{*}$ & $++^{*}$ \\
\hline $1: 1000$ & +++ & $++^{*}$ & $+^{*}$ & ++ & + & +++ & +++ & $++^{*}$ & $+^{*}$ & $+^{*}$ & $+^{*}$ \\
\hline
\end{tabular}

${ }^{*} p<0.001$ significant difference from control.

Table 5.

Production of staphylococcal enterotoxin type B (SEB) by S. aureus ATCC 14558 cultured with subinhibitory concentrations of phenolic compounds.

\begin{tabular}{|c|c|c|c|c|c|c|c|c|c|c|c|}
\hline \multirow[b]{2}{*}{ Dilution } & \multirow[b]{2}{*}{ Control } & \multicolumn{2}{|c|}{ Eugenol } & \multicolumn{2}{|c|}{ Terpineol } & \multicolumn{2}{|c|}{ Cinnamaldehyde } & \multicolumn{2}{|c|}{ Citronellol } & \multicolumn{2}{|c|}{ Geraniol } \\
\hline & & $60 \%$ & $80 \%$ & $60 \%$ & $80 \%$ & $60 \%$ & $80 \%$ & $60 \%$ & $80 \%$ & $60 \%$ & $80 \%$ \\
\hline $1: 1$ & +++ & $-^{*}$ & $-^{*}$ & $-{ }^{*}$ & $-^{*}$ & +++ & +++ & +++ & +++ & +++ & +++ \\
\hline $1: 10$ & +++ & $-^{*}$ & $-^{*}$ & $-^{*}$ & $-^{*}$ & +++ & +++ & +++ & +++ & +++ & +++ \\
\hline $1: 100$ & +++ & $-^{*}$ & $-^{*}$ & $-^{*}$ & $-{ }^{*}$ & +++ & +++ & +++ & +++ & +++ & +++ \\
\hline $1: 1000$ & +++ & $-^{*}$ & $-^{*}$ & $-^{*}$ & $-^{*}$ & +++ & +++ & ++ & ++ & +++ & +++ \\
\hline
\end{tabular}

${ }^{*} p<0.001$ significant difference from control.

consequently, influence enterotoxin production (Smith-Palmer, Stewart, \& Fyfe, 2004; Tranter, Tassou, \& Nychas, 1993). Treatment with subinhibitory concentrations of tea tree oil (Ter, a major compound) led to a dose-dependent decrease in SEA and SEB production, and a downregulation of exoprotein in S. aureus (Shi et al., 2016). The tea tree oil inhibited SEB production more effectively than SEA production (Shi et al., 2016). This trend was similar to that obtained in the current study. Qiu et al. (2010a) reported a dose-dependent suppression of SEA and SEB secretion by licochalcone A.

This phenotypic change possibly is due to the secretion of offside-related proteins to physical changes in bacterial plasmatic membrane caused by compounds (Nostro, Cannatelli, Musolino, Procopio, \& Alonzo, 2002; Shah, Stapleton, \& Taylor, 2008). Physical alterations in the plasma membrane can interfere with transmembrane transport processes, resulting in changes to protein secretions associated with $S$. aureus virulence (Ikigai, Toda, Okubo, Hara, \& Shimamura, 1990). Moreover, when antibiotics are used in subinhibitory concentrations, which have little or no effect on overall microbial growth, bacterial enzyme expression can still be affected (Souza, de Barros, de Oliveira, \& da Conceição, 2010). For example, protein synthesis inhibitors, such as linezolide, decreased the expression of $S$. aureus virulence factors, including SEA and SEB at subinhibitory concentrations (Bernardo et al.,
2004). Some studies with phenolic compounds have shown suppression of protein secretions, such as $\alpha$ - and $\gamma$-hemolysin, DNAse, lipase, coagulase and toxic shock syndrome toxin-1 (TSST-1) (Gemmell, 1995; Ohlsen et al., 1998; Shah et al., 2008).

The effects on enterotoxin production by phenolic compounds could have occurred at a number of points, including translation, transcription, export from the cell or direct inactivation of the toxin. Furthermore, EO compounds have a natural image and are more readily accepted by consumers than synthetic antimicrobial agents (SmithPalmer et al., 2004).

The clinical performance of antibiotics used to treat $S$. aureus infections depends not only on their bacteriostatic or bactericidal effects but also on their ability to prevent the release of virulence factors by dying or stressed bacteria (Bernardo et al., 2004). Many genes encoding virulence factors are coordinately regulated in response to a variety of intracellular and extracellular signals. It has been shown that subinhibitory concentrations of antibiotics may interfere with the translation of one or more regulatory gene products in S. aureus, which in turn affects transcription of exoprotein-encoding genes. The expression levels of TSST-1, SEB and $\alpha$-hemolysin are positively controlled by agr (accessory gene regulator), a locus that controls the expression of most of the exoprotein genes (Arvidson \& Tegmark, 2001; Peng, Novick,

Table 6.

Production of staphylococcal enterotoxin type C (SEC) by S. aureus ATCC 19095 cultured with subinhibitory concentrations of phenolic compounds.

\begin{tabular}{|c|c|c|c|c|c|c|c|c|c|c|c|}
\hline \multirow[b]{2}{*}{ Dilution } & \multirow[b]{2}{*}{ Control } & \multicolumn{2}{|c|}{ Eugenol } & \multicolumn{2}{|c|}{ Terpineol } & \multicolumn{2}{|c|}{ Cinnamaldehyde } & \multicolumn{2}{|c|}{ Citronellol } & \multicolumn{2}{|c|}{ Geraniol } \\
\hline & & $60 \%$ & $80 \%$ & $60 \%$ & $80 \%$ & $60 \%$ & $80 \%$ & $60 \%$ & $80 \%$ & $60 \%$ & $80 \%$ \\
\hline $1: 1$ & +++ & $+^{*}$ & $-^{*}$ & $+^{*}$ & $-^{*}$ & $+^{*}$ & $-^{*}$ & $+^{*}$ & $-^{*}$ & $-^{*}$ & $-{ }^{*}$ \\
\hline $1: 10$ & +++ & $-^{*}$ & $-^{*}$ & $-^{*}$ & $-{ }^{*}$ & $+^{*}$ & $-{ }^{*}$ & $-{ }^{*}$ & $-^{*}$ & $-^{*}$ & $-^{*}$ \\
\hline $1: 100$ & +++ & $-^{*}$ & $-^{*}$ & $-^{*}$ & $-{ }^{*}$ & $-{ }^{*}$ & $-^{*}$ & $-^{*}$ & $-^{*}$ & $-^{*}$ & $-^{*}$ \\
\hline $1: 1000$ & +++ & $-^{*}$ & $-^{*}$ & $-^{*}$ & $-{ }^{*}$ & $-{ }^{*}$ & $-^{*}$ & $-^{*}$ & $-^{*}$ & $-^{*}$ & $-^{*}$ \\
\hline
\end{tabular}

${ }^{*} p<0.001$ significant difference from control.

Table 7.

Production of staphylococcal enterotoxin type D (SED) by S. aureus and ATCC 23235 cultured with subinhibitory concentrations of phenolic compounds.

\begin{tabular}{|c|c|c|c|c|c|c|c|c|c|c|c|}
\hline \multirow[b]{2}{*}{ Dilution } & \multirow[b]{2}{*}{ Control } & \multicolumn{2}{|c|}{ Eugenol } & \multicolumn{2}{|c|}{ Terpineol } & \multicolumn{2}{|c|}{ Cinnamaldehyde } & \multicolumn{2}{|c|}{ Citronellol } & \multicolumn{2}{|c|}{ Geraniol } \\
\hline & & $60 \%$ & $80 \%$ & $60 \%$ & $80 \%$ & $60 \%$ & $80 \%$ & $60 \%$ & $80 \%$ & $60 \%$ & $80 \%$ \\
\hline $1: 1$ & +++ & +++ & +++ & +++ & +++ & +++ & +++ & +++ & +++ & +++ & +++ \\
\hline $1: 10$ & +++ & +++ & +++ & +++ & +++ & +++ & +++ & +++ & +++ & +++ & +++ \\
\hline $1: 100$ & +++ & +++ & +++ & +++ & +++ & +++ & +++ & +++ & ++ & +++ & +++ \\
\hline $1: 1000$ & +++ & $++^{*}$ & ++ & +++ & +++ & +++ & +++ & ++ & ++ & +++ & +++ \\
\hline
\end{tabular}

* $p<0.001$ significant difference from control. 
Kreiswirth, Kornblum, \& Schlievert, 1988). However, agr has no effect on SEA expression (Novick, 2003). Therefore, it is possible that the influence of subinhibitory concentrations of compounds on SEB and SEC depend on compound-induced inhibition of the agr system (Qiu et al., 2010b). Nevertheless, the mechanisms by which S. aureus regulates virulence gene expression are extremely complicated. This regulation involves an interactive, hierarchical regulatory cascade among the agr, sar and other regulatory gene products (Chan \& Foster, 1998).

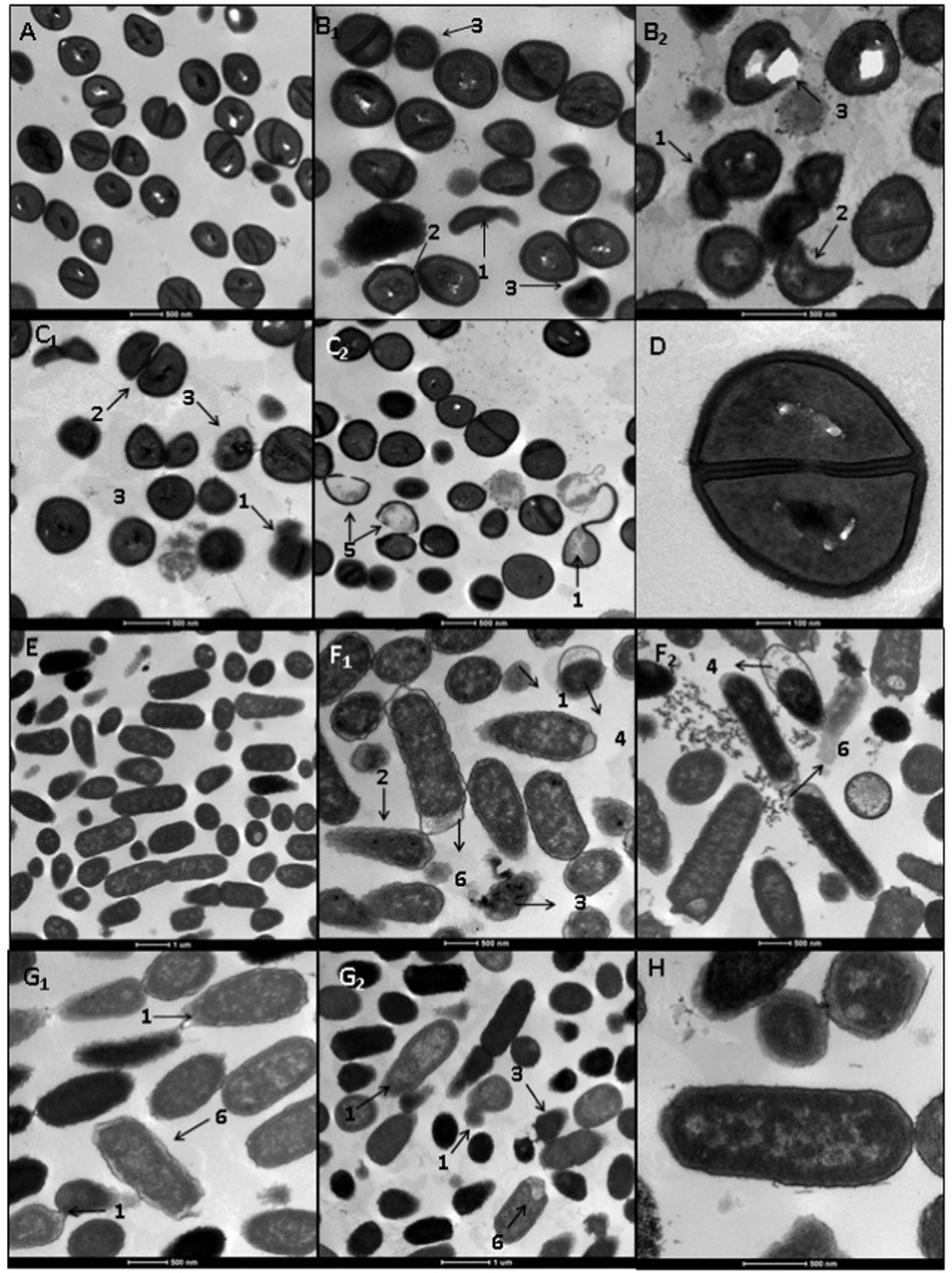

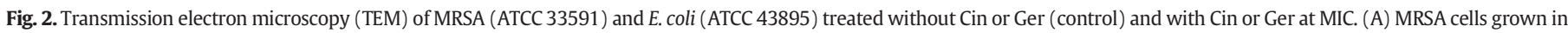

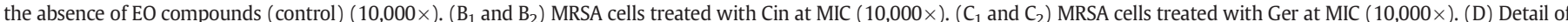

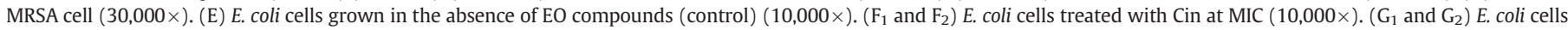

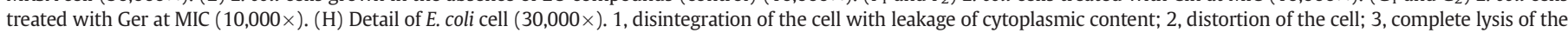
cell; 4 , polarization of cytoplasmic content; 5 , lack of cytoplasm; 6 , cytoplasmic membrane separated from the cell wall. 


\subsection{Effect of cinnamaldehyde and geraniol on bacterial morphology}

The morphologies of MRSA and E. coli cell ultrastructures treated with Cin and Ger were visualized by TEM (Fig. 2). Relative to the untreated cells of MRSA and E. coli (Fig. 2A and E), deformation of the bacterial cell membrane occurred on the addition of Cin and Ger. Both strains exhibited cell wall damage, and a complete loss of membrane integrity was evident (Fig. 2B, C, F and G). Treated MRSA cells exhibited several morphological changes, including separation of the cytoplasmic membrane from the cell wall, cell wall and cell membrane lysis, cytoplasmic content leakage, cytoplasmic content polarization, and cell distortion (Fig. 2B and C). Similar changes occurred in treated E. coli (Fig. 2F and $\mathrm{G}$ ). Additionally, the cytoplasmic content condensed (Fig. $2 \mathrm{G}_{1}$ and $\mathrm{G}_{2}$ ) due to abnormal protein precipitation.

According to Shen et al. (2015), E. coli and S. aureus suffered similar damages to those observed in this study, when exposed to MIC of Cin, including a loss of cell wall integrity. Chemical constituents of plantderived EOs, such as monoterpenes, as tested in the current study, are associated with cell membrane damage due to their hydrophobic nature; these compounds accumulate in the lipid-rich environments of cell membrane structures, causing structural and functional damage (Cox et al., 2000; Lambert, Skandamis, Coote, \& Nychas, 2001; Sikkema, De Bont, \& Poolman, 1995). Furthermore, they can dissolve in biomembranes and interact with lipophilic side chains of phospholipids (Wink, 2008). Although the exact mechanism remains unclear, evidence of physicochemical and physiological changes to cell structure and components has been reported, and more than one mechanism may be involved in the activity of phenolic compounds. However, the relevance of alternate mechanisms can be discounted if rapid inhibition of energy generation occurs. The possible mechanisms of inhibition of energy generation are inhibition of glucose uptake or utilization of glucose and effects on membrane permeability (Gill \& Holley, 2004).

\section{Conclusions}

This study illustrated the potential of phenolic compounds to interact synergistically with antimicrobial drugs against MRSA and to significantly decrease enterotoxin production by $S$. aureus. This is potentially of considerable importance in the food and pharmaceutical industries, and a promising area for further development.

\section{Acknowledgments}

The authors thank Fundação de Amparo à Pesquisa do Estado de São Paulo (FAPESP) for financial support for this work (2013/02446-6) and scholarship (2012/17368-8) granted to the author Mariana Albano; and Luciano Barbosa (IBB/UNESP/Botucatu) for statistical analysis.

\section{References}

Alves, F. C. B., Barbosa, L. N., Andrade, B. F. Albano M., Furtado, F. B., Pereira, A. F. M., Rall, V. L. M., \& Fernandes Júnior, A. (2016). Inhibitory activities of the lantibiotic nisin combined with phenolic compounds against Staphylococcus aureus and Listeria monocytogenes in cow milk. Journal of Dairy Science, 99(3), 1831-1836.

Andrade, B. F. M. T., Conti, B. J., Santiago, K. B., Fernandes Júnior, A., \& Sforcin, J. M. (2014). Cymbopogon martinii essential oil and geraniol at noncytotoxic concentrations exerted immunomodulatory/anti-inflammatory effects in human monocytes. Journal of Pharmacy and Pharmacology, 66(10), 1491-1496.

Arvidson, S., \& Tegmark, K. (2001). Regulation of virulence determinants in Staphylococcus aureus. International Journal of Medical Microbiology, 291(2), 159-170.

Astani, A., Reichling, J., \& Schnitzler, P. (2011). Screening for antiviral activities of isolated compounds from essential oils. Evidence Based Complementary Alternative Medicine, 2011 .

Barbosa, T. M., \& Levy, S. B. (2000). The impact of antibiotic use on resistance development and persistence. Drug Resistance Updates, 3(5), 303-311.

Barbosa, L. N., Probst, I. D. S., Andrade, B. F. M. T., Alves, F. C. B., Albano, M., Cunha, M. L. R. S., \& Fernandes Junior, A. (2015). In vitro antibacterial and chemical properties of essential oils including native plants from Brazil against pathogenic and resistant bacteria. Journal of Oleo Science, 64(3), 289-298.
Bernardo, K., Pakulat, N., Fleer, S., Schnaith, A., Utermöhlen, O., Krut, O., ... Krönke, M. (2004). Subinhibitory concentrations of linezolid reduce Staphylococcus aureus virulence factor expression. Antimicrobial Agents and Chemotherapy, 48(2), 546-555.

Bigos, M., \& Denys, A. (2008). The MRSA hospital infections. International Review of Allergology and Clinical Immunology, 14, 101-109.

Brenes, A., \& Roura, E. (2010). Essential oils in poultry nutrition: Main effects and modes of action. Animal Feed Science and Technology, 158(1), 1-14.

Budri, P. E., Silva, N. C. C., Bonsaglia, E. C. R., Fernandes Júnior, A., Araújo, J. P., Doyama, J. T., \& Rall, V. L. M. (2015). Effect of essential oils of Syzygium aromaticum and Cinnamomum zeylanicum and their major components on biofilm production in Staphylococcus aureus strains isolated from milk of cows with mastitis. Journal of Dairy Science, 98(9), 5899-5904.

Burt, S. (2004). Essential oils: Their antibacterial properties and potential applications in foods-a review. International Journal of Food Microbiology, 94(3), 223-253.

Chan, P. F., \& Foster, S. J. (1998). Role of SarA in virulence determinant production and environmental signal transduction in Staphylococcus aureus. Journal of Bacteriology, 180(23), 6232-6241.

Clinical and Laboratory Standards Institute (CLSI) (2012). Performance standards for antimicrobial susceptibility testing: 21st informational supplement (M100-S22). Wayne, PA: CLSI.

Cowan, M. M. (1999). Plant products as antimicrobial agents. Clinical Microbiology Reviews, 12(4), 564-582.

Cox, S. D., Mann, C. M., Markham, J. L., Bell, H. C., Gustafson, J. E., Warmington, J. R., \& Wyllie, S. G. (2000). The mode of antimicrobial action of the essential oil of Melaleuca alternifolia (tea lftree oil). Journal of Applied Microbiology, 88(1), 170-175.

Delamare, A. P. L., Moschen-Pistorello, I. T., Artico, L., Atti-Serafini, L., \& Echeverrigaray, S. (2007). Antibacterial activity of the essential oils of Salvia officinalis L. and Salvia triloba L. cultivated in South Brazil. Food Chemistry, 100(2), 603-608.

Enan, E. (2001). Insecticidal activity of essential oils: Octopaminergic sites of action. Comparative Biochemistry and Physiology. Section C Toxicology and Pharmacology, 130(3), 325-337.

Fernandes Júnior, A., Balestrin, E. C., Betoni, J. E. C., Orsi, R. D. O., Cunha, M. D. L. R. D., \& Montelli, A. C. (2005). Propolis: anti-Staphylococcus aureus activity and synergism with antimicrobial drugs. Memórias do Instituto Oswaldo Cruz, 100(5), 563-566.

Filgueiras, C. T., \& Vanetti, M. C. D. (2006). Effect of eugenol on growth and listeriolysin 0 production by Listeria monocytogenes. Brazilian Archives of Biology and Technology, 49(3), 405-409.

Fitzgerald, D. J., Stratford, M., \& Narbad, A. (2003). Analysis of the inhibition of food spoilage yeasts by vanillin. International Journal of Food Microbiology, 86(1), 113-122.

Gemmell, C. G. (1995). Antibiotics and the expression of staphylococcal virulence. Journal of Antimicrobial Chemotherapy, 36(2), 283-291.

George, D. R., Smith, T. J., Shiel, R. S., Sparagano, O. A. E., \& Guy, J. H. (2009). Mode of action and variability in efficacy of plant essential oils showing toxicity against the poultry red mite, Dermanyssus gallinae. Veterinary Parasitology, 161(3), 276-282.

Gill, A. O., \& Holley, R. A. (2004). Mechanisms of bactericidal action of cinnamaldehyde against Listeria monocytogenes and of eugenol against L. monocytogenes and Lactobacillus sakei. Applied and Environmental Microbiology, 70(10), 5750-5755.

Hamoud, R., Sporer, F., Reichling, J., \& Wink, M. (2012). Antimicrobial activity of a traditionally used complex essential oil distillate (Olbas® Tropfen) in comparison to its individual essential oil ingredients. Phytomedicine, 19(11), 969-976.

Hemaiswarya, S., Kruthiventi, A. K., \& Doble, M. (2008). Synergism between natural products and antibiotics against infectious diseases. Phytomedicine, 15(8), 639-652.

Hennekinne, J. A., Brun, V., De Buyser, M. L., Dupuis, A., Ostyn, A., \& Dragacci, S. (2009). Innovative application of mass spectrometry for the characterization of staphylococcal enterotoxins involved in food poisoning outbreaks. Applied and Environmental Microbiology, 75(3), 882-884.

Hu, Z. O., Zhao, W. H., Asano, N., Yoda, Y., Hara, Y. \& Shimamura, T. (2002). Epigallocatechin gallate synergistically enhances the activity of carbapenems against methicillinresistant Staphylococcus aureus. Antimicrobial Agents and Chemotherapy, 46(2), 558-560.

Ikigai, H., Toda, M., Okubo, S., Hara, Y., \& Shimamura, T. (1990). Relationship between the anti-hemolysin activity and the structure of catechins and theaflavins. Nippon Saikingaku Zasshi. Japanese Journal of Bacteriology, 45(6), 913-919.

Kaskatepe, B. Kiymaci, M. E. Suzuk, S, Erdem, S. A. Cesur, S., \& Yildiz, S. (2016). Antibacterial effects of cinnamon oil against carbapenem resistant nosocomial Acinetobacter baumannii and Pseudomonas aeruginosa isolates. Industrial Crops and Products, 81, 191-194.

Kim, S. I., Roh, J. Y., Kim, D. H., Lee, H. S., \& Ahn, Y. J. (2003). Insecticidal activities of aromatic plant extracts and essential oils against Sitophilus oryzae and Callosobruchus chinensis. Journal of Stored Products Research, 39(3), 293-303.

Kordali, S., Kotan, R. Mavi, A. Cakir, A. Ala, A. \& Yildirim, A. (2005). Determination of the chemical composition and antioxidant activity of the essential oil of Artemisia dracunculus and of the antifungal and antibacterial activities of Turkish Artemisia absinthium, A. dracunculus, Artemisia santonicum and Artemisia spicigera essential oils. Journal of Agricultural and Food Chemistry, 53(24), 9452-9458.

Lambert, R. J. W., Skandamis, P. N., Coote, P. J., \& Nychas, G. J. (2001). A study of the minimum inhibitory concentration and mode of action of oregano essential oil, thymol and carvacrol. Journal of Applied Microbiology, 91(3), 453-462.

Le Loir, Y., Baron, F., \& Gautier, M. (2003). Staphylococcus aureus and food poisoning. Genetics and Molecular Research, 2(1), 63-76.

Li, Y. Q., Kong, D. X., \& Wu, H. (2013). Analysis and evaluation of essential oil components of cinnamon barks using GC-MS and FTIR spectroscopy. Industrial Crops and Products, $41,269-278$

Li, W., Chen, H., He, Z., Han, C., Liu, S., \& Li, Y. (2015). Influence of surfactant and oil composition on the stability and antibacterial activity of eugenol nanoemulsions. LWTFood Science and Technology, 62(1), 39-47. 
Mahon, C. R., \& Manuselis, G., Jr. (1995). Textbook of diagnostic microbiology. Philadelphia: WB Saunders Co.

Mantovani, R. P., Rall, V. L. M., Batalha, J. E. N., Fernandes, A. A. H., \& Fernandes Júnior, A. (2008). Anti-coagulase-negative Staphylococcus activity of ethanolic extracts of propolis from two Brazilian regions and synergism with antimicrobial drugs by the e-test method. Journal of Venomous Animals and Toxins Including Tropical Diseases, 14(2), 357-365.

Martin, A., Camacho, M., Portaels, F., \& Palomino, J. C. (2003). Resazurin microtiter assay plate testing of Mycobacterium tuberculosis susceptibilities to second-line drugs: Rapid, simple, and inexpensive method. Antimicrobial Agents and Chemotherapy, 47(11), 3616-3619.

Mitić-Ćulafić, D., Vuković-Gačić, B. S., Knežević-Vukčević, J. B., Stanković, S., \& Simić, D. M. (2005). Comparative study on the antibacterial activity of volatiles from sage (Salvia officinalis L.). Archives of Biological Sciences, 57(3), 173-178.

Moosavy, M. H., Basti, A. A., Misaghi, A., Salehi, T. Z., Abbasifar, R., Mousavi, H. A. E., .. Noori, N. (2008). Effect of Zataria multiflora Boiss. Essential oil and nisin on Salmonella typhimurium and Staphylococcus aureus in a food model system and on the bacterial cell membranes. Food Research International, 41(10), 1050-1057.

Moritz, C. M. F., Barbosa, L., Saeki, M. J., \& Fernandes Júnior, A. (2015). Assessment of antimicrobial activity of cinnamon (Cinnamomum zeylanicum) essential oil combined with EDTA and polyethylene glycol in yogurt. Acta Scientiarum-technology, 37(1), 99-104.

Mourey, A., \& Canillac, N. (2002). Anti-Listeria monocytogenes activity of essential oils components of conifers. Food Control, 13(4), 289-292.

Nascimento, P. F., Nascimento, A. C., Rodrigues, C. S., Antoniolli, A. R., Santos, P. O., Barbosa-Júnior, A. M., \& Trindade, R. C. (2007). Antimicrobial activity of the essentials oils: A multifactor approach of the methods. Brazilian Journal of Pharmacognosy, 17(1), 108-113.

Nostro, A., Cannatelli, M. A., Musolino, A. D., Procopio, F., \& Alonzo, V. (2002). Helichrysum italicum extract interferes with the production of enterotoxins by Staphylococcus aureus. Letters in Applied Microbiology, 35(3), 181-184

Novick, R. P. (2003). Autoinduction and signal transduction in the regulation of staphylococcal virulence. Molecular Microbiology, 48(6), 1429-1449.

Ohlsen, K., Ziebuhr, W., Koller, K. P., Hell, W., Wichelhaus, T. A., \& Hacker, J. (1998). Effects of subinhibitory concentrations of antibiotics on alpha-toxin ( $h l a)$ gene expression of methicillin-sensitive and methicillin-resistant Staphylococcus aureus isolates. Antimicrobial Agents and Chemotherapy, 42(11), 2817-2823.

Ooi, L. S., Li, Y., Kam, S. L., Wang, H., Wong, E. Y., \& Ooi, V. E. (2006). Antimicrobial activities of cinnamon oil and cinnamaldehyde from the Chinese medicinal herb Cinnamomum cassia Blume. The American Journal of Chinese Medicine, 34(03), 511-522.

Oussalah, M., Caillet, S., Saucier, L., \& Lacroix, M. (2007). Inhibitory effects of selected plant essential oils on the growth of four pathogenic bacteria: E. coli 0157: H7, Salmonella typhimurium, Staphylococcus aureus and Listeria monocytogenes. Food Control, 18(5), 414-420.

Palaniappan, K., \& Holley, R. A. (2010). Use of natural antimicrobials to increase antibiotic susceptibility of drug resistant bacteria. International Journal of Food Microbiology, 140(2), 164-168.

Peng, H. L., Novick, R. P., Kreiswirth, B., Kornblum, J., \& Schlievert, P. (1988). Cloning, characterization, and sequencing of an accessory gene regulator (agr) in Staphylococcus aureus. Journal of Bacteriology, 170(9), 4365-4372.

Qian, M., Tang, S., Wu, C., Wang, Y., He, T., Chen, T., \& Xiao, X. (2015). Synergy between baicalein and penicillins against penicillinase-producing Staphylococcus aureus. International Journal of Medical Microbiology, 305(6), 501-504.

Qiu, J., Feng, H., Xiang, H., Wang, D., Xia, L., Jiang, Y., ... Deng, X. (2010a). Influence of subinhibitory concentrations of licochalcone $A$ on the secretion of enterotoxins $A$ and $B$ by Staphylococcus aureus. FEMS Microbiology Letters, 307(2), 135-141.

Qiu, J., Jiang, Y., Xia, L., Xiang, H., Feng, H., Pu, S., \& Deng, X. (2010b). Subinhibitory concentrations of licochalcone A decrease alpha-toxin production in both methicillin-sensitive and methicillin-resistant Staphylococcus aureus isolates. Letters in Applied Microbiology, 50(2), 223-229.

Rochon-Edouard, S., Pestel-Caron, M., Lemeland, J. F., \& Caron, F. (2000). In vitro synergistic effects of double and triple combinations of $\beta$-lactams, vancomycin, and netilmicin against methicillin-resistant Staphylococcus aureus strains. Antimicrobial Agents and Chemotherapy, 44(11), 3055-3060.

Schuenzel, K. M., \& Harrison, M. A. (2002). Microbial antagonists of foodborne pathogens on fresh, minimally processed vegetables. Journal of Food Protection, 65(12), 1909-1915.

Shah, S., Stapleton, P. D., \& Taylor, P. W. (2008). The polyphenol (-)-epicatechin gallate disrupts the secretion of virulence-related proteins by Staphylococcus aureus. Letters in Applied Microbiology, 46(2), 181-185.
Shen, S., Zhang, T., Yuan, Y., Lin, S., Xu, J., \& Ye, H. (2015). Effects of cinnamaldehyde on Escherichia coli and Staphylococcus aureus membrane. Food Control, 47, 196-202.

Shi, C., Zhao, X., Yan, H., Meng, R., Zhang, Y., Li, W., ... Guo, N. (2016). Effect of tea tree oil on Staphylococcus aureus growth and enterotoxin production. Food Control, 62, 257-263.

Shimizu, M., Shiota, S., Mizushima, T., Ito, H., Hatano, T., Yoshida, T., \& Tsuchiya, T. (2001). Marked potentiation of activity of $\beta$-lactams against methicillin-resistant Staphylococcus aureus by corilagin. Antimicrobial Agents and Chemotherapy, 45(11), 3198-3201.

Shiota, S., Shimizu, M., Mizusima, T., Ito, H., Hatano, T., Yoshida, T., \& Tsuchiya, T. (2000) Restoration of effectiveness of $\beta$-lactams on methicillin-resistant Staphylococcus aureus by tellimagrandin I from rose red. FEMS Microbiology Letters, 185(2), 135-138.

Sikkema, J., De Bont, J. A., \& Poolman, B. (1995). Mechanisms of membrane toxicity of hydrocarbons. Microbiological Reviews, 59(2), 201-222.

Silva, N. C. C., Barbosa, L., Seito, L. N., \& Fernandes Júnior, A. (2012). Antimicrobial activity and phytochemical analysis of crude extracts and essential oils from medicinal plants. Natural Product Research, 26(16), 1510-1514.

Silva, N. C. C., Barbosa, L. N., Andrade, B. F. T., Probst, I. S., Doyama, J. T., \& Fernandes Júnior, A. (2013). Synergism of crude extracts and essential oils from medicinal plants with antimicrobial drugs. Journal of Antimicrobials, 128, 189-197.

Smith-Palmer, A., Stewart, J., \& Fyfe, L. (2004). Influence of subinhibitory concentrations of plant essential oils on the production of enterotoxins A and B and $\alpha$-toxin by Staphylococcus aureus. Journal of Medical Microbiology, 53(10), 1023-1027.

Song, Y., Liu, C. I., Lin, F. Y., No, J. H., Hensler, M., Liu, Y. L., ... Wang, A. H. J. (2009). Inhibition of staphyloxanthin virulence factor biosynthesis in Staphylococcus aureus: In vitro, in vivo and crystallographic results. Journal of Medicinal Chemistry, 52(13), 3869-3880.

Souza, E. L., de Barros, J. C., de Oliveira, C. E. V., \& da Conceição, M. L. (2010). Influence of Origanum vulgare L. essential oil on enterotoxin production, membrane permeability and surface characteristics of Staphylococcus aureus. International Journal of Food Microbiology, 137(2), 308-311.

Stepanovic, S., Antic, N., Dakic, I., \& Svabic-Vlahovic, M. (2003). In vitro antimicrobial activity of propolis and synergism between propolis and antimicrobial drugs. Microbiology Research, 158(4), 353-357.

Tenover, F. C. (2006). Mechanisms of antimicrobial resistance in bacteria. The American Journal of Medicine, 119(6), S3-S10.

Tepe, B., Daferera, D., Sökmen, M., Polissiou, M., \& Sökmen, A. (2004). In vitro antimicrobial and antioxidant activities of the essential oils and various extracts of Thymus eigii M. Zohary et PH Davis. Journal of Agricultural and Food Chemistry, 52(5), 1132-1137.

Thomas, J., \& Kuruvilla, K. M. (2012). Cinnamon. Handbook of herbs and spices (2nd ed.). In Volume in Woodhead publishing series in Food Science, Technology and Nutrition (2nd ed.), 1. (pp. 182-196), 182-196.

Tohidpour, A., Sattari, M., Omidbaigi, R., Yadegar, A., \& Nazemi, J. (2010). Antibacterial effect of essential oils from two medicinal plants against methicillin-resistant Staphylococcus aureus (MRSA). Phytomedicine, 17(2), 142-145.

Tranter, H. S., Tassou, S. C., \& Nychas, G. J. (1993). The effect of the olive phenolic compound, oleuropein, on growth and enterotoxin B production by Staphylococcus aureus. Journal of Applied Bacteriology, 74(3), 253-259.

Walsh, S. E. Maillard, J. Y. Russell, A. D. Catrenich, C. E. Charbonneau, D. L. \& Bartolo, R. C. (2003). Activity and mechanisms of action of selected biocidal agents on Gram-positive and -negative bacteria. Journal of Applied Microbiology, 94(2), 240-247.

Wang, R., Wang, R., \& Yang, B. (2009). Extraction of essential oils from five cinnamon leaves and identification of their volatile compound compositions. Innovative Food Science \& Emerging Technologies, 10(2), 289-292.

Wink, M. (2008). Evolutionary advantage and molecular modes of action of multicomponent mixtures used in phytomedicine. Current Drug Metabolism, 9(10), 996-1009.

Zago, J. A., Ushimaru, P. I., Barbosa, L. N., \& Fernandes Junior, A. (2009). Synergism between essential oils and antimicrobial drugs against Staphyloccus aureus and Escherichia coli strains from human infections. Revista Brasileira de Farmacognosia, 19(4), 828-833.

Zhao, W. H., Hu, Z. Q., Hara, Y., \& Shimamura, T. (2002). Inhibition of penicillinase by epigallocatechin gallate resulting in restoration of antibacterial activity of penicillin against penicillinase-producing Staphylococcus aureus. Antimicrobial Agents and Chemotherapy, 46(7), 2266-2268.

Zhu, H., Du, M., Fox, L., \& Zhu, M. J. (2016). Bactericidal effects of Cinnamon cassia oil against bovine mastitis bacterial pathogens. Food Control, 66, 291-299. 